\title{
A SIMULATION STUDY OF THE APPROPRIATE BULK DENSITY AND DEPTH OF THE PLOW LAYER IN A SOYBEAN (GLYCINE $M A X$ (L.) MERR) FIELD OF THE NORTHEAST BLACK SOIL REGION OF CHINA
}

\author{
KANG, S. - YU, L. - GONG, Z. P. \\ College of Agriculture, Northeast Agricultural University, Harbin 150030, China \\ *Corresponding author \\ e-mail: gzpyx2004@163.com
}

(Received $9^{\text {th }}$ May 2019; accepted $20^{\text {th }}$ Aug 2019)

\begin{abstract}
We studied the different patterns of nutrient accumulation, root-shoot ratio, and yield of soybean plants observed in response to the changes in the soil bulk density and plow depth; this was achieved by adopting the frame-planting method and taking two soybean varieties, Jiyu 79 (JY79) and Heinong 44 (HN44), as the test materials. The results showed that soybean dry matter; the accumulation of nitrogen $(\mathrm{N})$, phosphorous $(\mathrm{P})$, and potassium $(\mathrm{K})$; and the yield had a single-peak curve change at the bulk density of $1.00 \mathrm{~g} / \mathrm{cm}^{3}-1.45 \mathrm{~g} / \mathrm{cm}^{3}$, with the most appropriate soybean growth and yield observed at the bulk density of $1.15 \mathrm{~g} / \mathrm{cm}^{3}-1.30 \mathrm{~g} / \mathrm{cm}^{3}$. Soybean dry matter; $\mathrm{N}, \mathrm{P}$, and $\mathrm{K}$ accumulation; and yield with the increase in plow depth, with the $30 \mathrm{~cm}$ plow depth being the optimal plow depth for the soybean field. The root-shoot ratio of the soybean plants was relatively high during the early growth period and decreased with the progression of the growth. In the $\mathrm{R}_{1}$ stage, the root-shoot ratio showed a "V"-shaped change with the increase in bulk density in the plow layer, with the smallest root-shoot ratio occurring under the treatment with the bulk density of $1.30 \mathrm{~g} / \mathrm{cm}^{3}$; in the $R_{5}$ and $R_{8}$ stages, the root-shoot ratio was not significantly affected when the bulk density in the plow layer was between $1.00 \mathrm{~g} / \mathrm{cm}^{3}$ and $1.30 \mathrm{~g} / \mathrm{cm}^{3}$, but the root-shoot ratio significantly increased under the treatment with the bulk density of $1.45 \mathrm{~g} / \mathrm{cm}^{3}$. In the $\mathrm{R}_{1}$ stage, no significant difference existed in the root-shoot ratio between the treatments with plow depths of $0-20 \mathrm{~cm}$, and their root-shoot ratios were higher than those under the treatment with plow depths of 30 and $40 \mathrm{~cm}$; in the $\mathrm{R}_{5}$ and $\mathrm{R}_{8}$ stages, no significant difference existed in the root-shoot ratio between the 10 to $40 \mathrm{~cm}$ plow depths.
\end{abstract}

Keywords: bulk density, plow depth, soybean, nutrient accumulation, yield, root-shoot ratio

\section{Introduction}

The average soil bulk density of China's terrestrial ecosystems is $1.32 \mathrm{~g} / \mathrm{cm}^{3}$. Soil bulk density increases with the depth of the soil layer (Chai and He, 2016) and has a significant effect on the soil water content characteristics (Blouin et al., 2004; Zhong et al., 2016). Soil bulk density also affects the soil microbial community structure (Kaiser et al., 1991) and physiological characteristics (Williams and Rice, 2007), thereby affecting the physiological and biochemical indicators and dry matter accumulation in crops (Assaeed et al., 1990; Siczek et al., 2013). Buttery et al. (1998) found that when bulk density increased from $1.2 \mathrm{~g} / \mathrm{cm}^{3}$ to $1.5 \mathrm{~g} / \mathrm{cm}^{3}$ in clay loam and $1.6 \mathrm{~g} / \mathrm{cm}^{3}$ in sandy loam, the soybean dry matter and root weight decreased significantly (Nunes et al., 2015a); the increased bulk density also reduced the number of pea root nodules and the root nodule dry weight, as well as the nitrogen $(\mathrm{N})$ fixation enzyme activities and total N content (Siczek and Lipiec, 2011; Siczek et al., 2013).

Soil bulk density is an important indicator of soil physical properties. Excessive bulk density results in a decrease in the number of large pores in the soil, an increase in the soil compaction, and a decrease in the gas exchange rate (Kaiser et al., 1991). 
Differences in soil compactness can have a significant impact on the growth and penetration of the crop roots (Colombi and Walter, 2016; Maganti et al., 2005). Siczek et al. (2015) found that the root number, root dry weight, root length, and root vigor of the crops all decreased with the increase in bulk density and that the increase in soil bulk density interfered with the growth of the pea roots and plants, leading to thicker roots and thus to less uptake of nutrients. Bengough et al. (1994) found that when soil bulk density was increased from $0.85 \mathrm{~g} / \mathrm{cm}^{3}$ to $1.40 \mathrm{~g} / \mathrm{cm}^{3}$, the growth rate of the pea roots was significantly reduced, and when the root growth encountered an increased resistance, the pea root elongation rate was decreased by $50 \%$ within half an hour; after the resistance was removed, the root growth rate increased slightly. The responses of the different crops to soil compactness are basically the same. Rosolem et al. (1998) studied the effect of soil compaction on the growth of cotton roots and showed that when the soil strength reached $2.5 \mathrm{MPa}$, the cotton roots would no longer grow. Freitas et al. (1999) disclosed that when the compaction of the soil increases, the morphology pattern of the lateral roots of maize also changes correspondingly, developing a thicker root diameter, a greater number of lateral roots and root hairs, and changing their direction of growth (Barley, 1962; Goss and Russell, 1980). Iijima et al. (1991) found that an excessive soil bulk density in the lower soil layers would inhibit growth in rice roots and corn roots, which in turn would promote the formation of lateral roots in the upper layer; this finding indicates that the growth of roots in different soil layers exhibits certain compensation effects. The results of previous studies in our laboratory showed that the effect of the soil bulk density on the $\mathrm{N}$ content and accumulation amount in soybean exhibits a parabolic change in trend, with soils that are too loose or too tight soil being unfavorable (Zhang et al., 2017). Johnson et al. (1989) found that the compaction in the 0 to $30 \mathrm{~cm}$ surface soil layer reduced the soybean yield by $15 \%$, but the compaction of subsoil below the $30 \mathrm{~cm}$ layer had little effect on soybean yield. Gaultney et al. (1980) reported that the compaction of soil at lower layers can significantly affect the growth and final yield of corn. Bushamuka and Zobel (1998) argued that when the soil layer bulk density was $1.6 \mathrm{~g} / \mathrm{cm}^{3}$, the corn root system could not penetrate. However, Stypa et al. (1987) claimed that bulk density threshold in the soil layer for corn root growth could reach $1.8 \mathrm{~g} / \mathrm{cm}^{3}$. Increasing the subsoiling depth can effectively reduce the soil bulk density in the lower layers (Wang et al., 2015), which essentially increases the plow depth and increases the crop yield (Nunes et al., 2015b). Qi et al. (2015) conducted a subsoiling test under the same regional conditions, and the results showed that the resistance of the subsoiling blade increased in a quadratic curve as the subsoiling depth increased in the subsoiling operation. The above studies show that crop growth and yield have an appropriate range of bulk density and depth in the plow layer (Gayosso-Moralesl et al., 2017; Gomez-Lopez et al., 2018; Ufuk Kasim and Kasim, 2017; Vicente-Molina et al., 2018). When the bulk density in the plow layer is greater than the appropriate bulk density, the soil should be loosened; when the bulk density is too loose, the soil should be compacted. The tillage depth should be within the range of the appropriate plow depth, whereas tilling too deep would increase the cost and would not achieve the effect of increasing production ( $\mathrm{Fu}$ and Liu, 2017; Peng et al., 2017).

The Northeast black soil region in China is the main soybean-producing area in China. The appropriate ranges of bulk density and plow depth in the plow layer in this region have not been determined by systematic study. In this study, the frame-planting method was used to simulate different bulk densities and plow depths to study their 
effects on the growth and yield of the soybeans, thereby providing a theoretical basis for determining the appropriate bulk density and plow depth in the plow layer of the soybean field and providing a reference for scientific farming of field soybeans.

\section{Materials and methods}

\section{Test materials}

The experiment was conducted using the frame-planting method in the research field of the college of Agriculture, Northeast Agricultural University, China, in 2016. The round frame was made from a PVC circular tube (with an inner diameter of $20 \mathrm{~cm}$, a height of $45 \mathrm{~cm}$, and no bottom); $40 \mathrm{~cm}$ of the soil was packed, and the upper frame extended to $5 \mathrm{~cm}$ above the soil layer. The test soil was taken from the maize field and was of the black soil type (with a soil specific gravity of 2.65). Soil organic matter was $32.49 \mathrm{~g} / \mathrm{kg}$, available $\mathrm{N}$ was $65.01 \mathrm{mg} / \mathrm{kg}$, available phosphorus (P) was $60.53 \mathrm{mg} / \mathrm{kg}$, and available potassium (K) was $192.45 \mathrm{mg} / \mathrm{kg}$. Soybean varieties included the Jiyu 79 (JY79) and Heinong 44 (HN44). The fertilizer application rate included $0.47 \mathrm{~g}\left(150 \mathrm{~kg} / \mathrm{hm}^{2}\right)$ of diammonium hydrogen phosphate $\left(\mathrm{P}_{2} \mathrm{O}_{5}: 46 \%\right)$ per frame and $0.24 \mathrm{~g}\left(75 \mathrm{~kg} / \mathrm{hm}^{2}\right)$ of potassium sulfate $\left(\mathrm{K}_{2} \mathrm{O}: 54 \%\right)$ per frame.

\section{Experimental design}

The soil density of the 20 to $30 \mathrm{~cm}$ soil layer of farmland in the black soil region was approximately $1.43 \mathrm{~g} / \mathrm{cm}^{3}$ (Zhao et al., 2010). The maximum value of the soil bulk density in this study was set as $1.45 \mathrm{~g} / \mathrm{cm}^{3}$.

Bulk density treatment: Four bulk density levels, including $1.00 \mathrm{~g} / \mathrm{cm}^{3}, 1.15$ $\mathrm{g} / \mathrm{cm}^{3}, 1.30 \mathrm{~g} / \mathrm{cm}^{3}$, and $1.45 \mathrm{~g} / \mathrm{cm}^{3}$, were established and respectively denoted by B1.00, B1.15, B1.30, and B1.45. For each bulk density treatment, 30 frames were included, for a total of 120 frames in this study. The method was applied as follows: by measuring the soil water content, the weight of the soil $40 \mathrm{~cm}$ high in the frame was calculated, and a jack was used to compact the test soil in the round frame according to the different bulk density settings.

Plow depth treatment: The test soil within the round frame was divided into two layers (upper and lower layers) for simulation; that is, the upper layer was taken as the plow layer, and the lower layer was the layer below the plow layer. The soil bulk density in the plow layer was uniformly set to be $1.15 \mathrm{~g} / \mathrm{cm}^{3}$, and the soil bulk density in the layer below the plow layer was uniformly set to be $1.45 \mathrm{~g} / \mathrm{cm}^{3}$. Five plow depths were included, which were $0 \mathrm{~cm}, 10 \mathrm{~cm}, 20 \mathrm{~cm}, 30 \mathrm{~cm}$, and $40 \mathrm{~cm}$, respectively, and these depths were denoted as D0, D10, D20, D30, and D40, respectively. For each plow depth treatment, 30 frames were included, for a total of 150 frames. Specifically, for D0, the bulk density of the $40 \mathrm{~cm}$ of soil within the round frame was uniformly set as $1.45 \mathrm{~g} / \mathrm{cm}^{3}$; for D10, the bulk density of the upper $10 \mathrm{~cm}$ soil layer within the frame was set as $1.15 \mathrm{~g} / \mathrm{cm}^{3}$, and the bulk density of the lower $30 \mathrm{~cm}$ soil layer was set as $1.45 \mathrm{~g} / \mathrm{cm}^{3}$; for D20, the bulk density of the upper $20 \mathrm{~cm}$ soil layer within the round frame was set as $1.15 \mathrm{~g} / \mathrm{cm}^{3}$, and the bulk density of the lower $20 \mathrm{~cm}$ soil layer was set as $1.45 \mathrm{~g} / \mathrm{cm}^{3}$; for D30, the bulk density of the upper $30 \mathrm{~cm}$ soil layer with the round frame was set as $1.15 \mathrm{~g} / \mathrm{cm}^{3}$, and the bulk density of the lower $10 \mathrm{~cm}$ soil layer was set as $1.45 \mathrm{~g} / \mathrm{cm}^{3}$; and for D40, the $40 \mathrm{~cm}$ 
soil bulk density in the round frame was uniformly set as $1.15 \mathrm{~g} / \mathrm{cm}^{3}$. A jack was used to first compact the soil below the plow layer and then to compact the upper soil.

For sowing, the soil within the frame was watered to saturation, and then, four seeds were sown in hills and covered with $3 \mathrm{~cm}$ of soil; after seedling emergence, final thinning of the seedlings was conducted, with two plants being retained per frame.

\section{Sampling and nutrient determination}

Sampling methods: Samples were taken at the $\mathrm{R}_{1}$ (incipient flowering stage), $\mathrm{R}_{5}$ (granule stage), and $R_{8}$ (maturity stage). During sampling, the aboveground part of the soybean plant was removed at the cotyledon trace, and the roots were rinsed with clean water. The various parts were respectively placed in different envelopes, which were subjected to fixation at $105{ }^{\circ} \mathrm{C}$ for $30 \mathrm{~min}$ and oven drying at $65^{\circ} \mathrm{C}$; samples were weighed for determination of the nutrient contents.

Nutrient determination: Plant $\mathrm{N}$ and $\mathrm{P}$ contents, respectively, were measured by using $\mathrm{CuSO}_{4}$ and $\mathrm{K}_{2} \mathrm{SO}_{4}$ as catalysts, and after digestion of the sample with concentrated $\mathrm{H}_{2} \mathrm{SO}_{4}$, the $\mathrm{N}$ was measured by the Kjeldahl method, and the $\mathrm{P}$ was measured by the molybdenum antimony anti-colorimetric method. Following digestion of the sample by the concentrated $\mathrm{H}_{2} \mathrm{SO}_{4}$, the $\mathrm{K}$ content in the plants was determined by the flame spectrophotometry method by using hydrogen peroxide as a catalyst.

The accumulated amounts of $\mathrm{N}, \mathrm{P}$, and $\mathrm{K}$ were determined, respectively, by multiplying the corresponding $\mathrm{N}, \mathrm{P}$, and $\mathrm{K}$ content by the dry matter amount.

\section{Results and analysis}

\section{Effects of soil bulk density and plow layer on soybean nutrient accumulation}

\section{Effect of soil bulk density on soybean nutrient accumulation}

Table 1 shows the dynamics of the dry matter accumulation and the accumulation of the $\mathrm{N}, \mathrm{P}$, and $\mathrm{K}$ in soybean plants under the different soil bulk density conditions. As show in Table 1, under the four bulk density levels, the dry matter and the N, P, and $\mathrm{K}$ accumulation amounts of the two test soybean varieties increased with the progression of the growth stages. The dry matter and the $\mathrm{N}, \mathrm{P}$, and $\mathrm{K}$ accumulation amounts for the two test varieties under the various soil bulk density treatments showed a descending order of $\mathrm{B} 1.30>\mathrm{B} 1.15>\mathrm{B} 1.00>\mathrm{B} 1.45$, showing a singlepeak curve with the increase in soil bulk density. Specifically, in the $\mathrm{R}_{1}$ stage, the dry matter and $\mathrm{K}$ accumulation amounts for the two varieties, as well as the $\mathrm{N}$ accumulation amount for JY79, were not significantly different between the B1.30 and $\mathrm{B} 1.15$ treatments; in the $\mathrm{R}_{5}$ stage, the dry matter and the $\mathrm{K}$ accumulation amounts for the two test soybean varieties, as well as the $\mathrm{N}$ accumulation amount for HN44, were not significantly different between the B1.30 and B1.15 treatments; and in the $\mathrm{R}_{8}$ stage, the $\mathrm{P}$ accumulation amounts for the two test soybean varieties were not significantly different between the B1.30 and B1.15 treatments. In the other stages, the B1.30 treatment showed significantly higher nutrient accumulation than the other treatments. 
Table 1. Effect of soil bulk density on soybean nutrient accumulation

\begin{tabular}{|c|c|c|c|c|c|c|}
\hline Variety & Period & Dispose & $\begin{array}{c}\text { Dry matter } \\
\text { quantity } \\
\left(\mathrm{g} \cdot \text { case }^{-1}\right)\end{array}$ & $\begin{array}{c}\text { Nitrogen } \\
\text { accumulation } \\
\left(\mathbf{m g} \cdot \operatorname{case}^{-1}\right)\end{array}$ & $\begin{array}{l}\text { Phosphorus } \\
\text { accumulation } \\
\left(\mathrm{mg}^{\left.-\operatorname{case}^{-1}\right)}\right.\end{array}$ & $\begin{array}{c}\text { Potassium } \\
\text { accumulation } \\
\left(\mathrm{mg}^{\left.- \text {case }^{-1}\right)}\right.\end{array}$ \\
\hline \multirow{15}{*}{ JY79 } & \multirow{5}{*}{$\mathrm{R}_{1}$} & B1.00 & $12.4 \pm 0.20 b$ & $353.2 \pm 5.83 b$ & $46.8 \pm 0.78 c$ & $206.7 \pm 3.41 b$ \\
\hline & & B1.15 & $15.9 \pm 0.30 \mathrm{a}$ & $548.4 \pm 9.64 a$ & $61.5 \pm 0.80 b$ & $268.9 \pm 3.72 \mathrm{a}$ \\
\hline & & B1.30 & $15.8 \pm 0.32 \mathrm{a}$ & $551.5 \pm 11.3 \mathrm{a}$ & $67.4 \pm 1.37 \mathrm{a}$ & $277.9 \pm 5.67 \mathrm{a}$ \\
\hline & & B1.45 & $5.8 \pm 0.12 c$ & $144.7 \pm 3.23 c$ & $21.0 \pm 0.44 \mathrm{~d}$ & $89.0 \pm 1.84 c$ \\
\hline & & Mean & 12.5 & 399.5 & 38.7 & 210.6 \\
\hline & \multirow{5}{*}{$\mathrm{R}_{5}$} & B1.00 & $63.5 \pm 0.98 b$ & $2058.3 \pm 31.41 c$ & $166.8 \pm 2.52 c$ & $763.3 \pm 10.87 b$ \\
\hline & & B1.15 & $68.9 \pm 1.57 \mathrm{ab}$ & $2428.1 \pm 51.39 b$ & $203.3 \pm 3.91 b$ & $939.6 \pm 18.41 \mathrm{a}$ \\
\hline & & B1.30 & $74.4 \pm 1.64 \mathrm{a}$ & $2689.3 \pm 58.67 \mathrm{a}$ & $215.7 \pm 4.72 \mathrm{a}$ & $985.1 \pm 19.1 \mathrm{a}$ \\
\hline & & B1.45 & $16.4 \pm 0.80 \mathrm{c}$ & $453.0 \pm 21.99 \mathrm{~d}$ & $42.0 \pm 1.99 \mathrm{~d}$ & $174.2 \pm 8.05 \mathrm{c}$ \\
\hline & & Mean & 41.6 & 1899.7 & 157.0 & 715.6 \\
\hline & \multirow{5}{*}{$\mathrm{R}_{8}$} & B1.00 & $145.4 \pm 0.78 c$ & $4783.1 \pm 29.83 c$ & $412.4 \pm 2.75 b$ & $1636.2 \pm 11.22 \mathrm{c}$ \\
\hline & & B1.15 & $168.0 \pm 2.49 b$ & $6024.9 \pm 100.98 b$ & $539.2 \pm 14.11 \mathrm{a}$ & $2084.9 \pm 35.35 b$ \\
\hline & & B1.30 & $181.5 \pm 1.16 \mathrm{a}$ & $6313.8 \pm 17.66 a$ & $539.7 \pm 5.65 \mathrm{a}$ & $2225.2 \pm 44.12 \mathrm{a}$ \\
\hline & & B1.45 & $42.9 \pm 1.66 \mathrm{~d}$ & $1303.4 \pm 28.26 \mathrm{~d}$ & $117.8 \pm 1.78 \mathrm{c}$ & $448.8 \pm 8.07 \mathrm{~d}$ \\
\hline & & Mean & 134.5 & 4606.3 & 402.3 & 1598.8 \\
\hline \multirow{15}{*}{ HN44 } & \multirow{5}{*}{$\mathrm{R}_{1}$} & B1.00 & $13.1 \pm 0.44 b$ & $402.0 \pm 13.06 \mathrm{c}$ & $42.2 \pm 1.33 c$ & $189.3 \pm 6.59 b$ \\
\hline & & B1.15 & $14.0 \pm 0.19 \mathrm{ab}$ & $453.7 \pm 5.60 \mathrm{~b}$ & $47.8 \pm 0.59 b$ & $218.1 \pm 3.52 \mathrm{a}$ \\
\hline & & B1.30 & $14.7 \pm 0.15 \mathrm{a}$ & $497.5 \pm 4.12 \mathrm{a}$ & $51.4 \pm 0.44 \mathrm{a}$ & $222.3 \pm 2.32 \mathrm{a}$ \\
\hline & & B1.45 & $6.0 \pm 0.16 c$ & $143.8 \pm 3.86 \mathrm{~d}$ & $21.4 \pm 0.57 \mathrm{~d}$ & $78.4 \pm 2.12 \mathrm{c}$ \\
\hline & & Mean & 12.0 & 374.3 & 40.7 & 177.0 \\
\hline & \multirow{5}{*}{$\mathrm{R}_{5}$} & B1.00 & $80.8 \pm 1.58 b$ & $2418.3 \pm 45.40 \mathrm{~b}$ & $215.9 \pm 4.22 c$ & $1001.3 \pm 20.89 b$ \\
\hline & & B1.15 & $86.4 \pm 1.83 \mathrm{ab}$ & $2744.0 \pm 65.22 \mathrm{a}$ & $234.5 \pm 5.11 b$ & $1117.5 \pm 23.45 \mathrm{a}$ \\
\hline & & B1.30 & $89.1 \pm 1.36 \mathrm{a}$ & $2834.0 \pm 43.50 \mathrm{a}$ & $251.9 \pm 3.56 \mathrm{a}$ & $1173.8 \pm 13.44 \mathrm{a}$ \\
\hline & & B1.45 & $27.0 \pm 0.48 \mathrm{c}$ & $704.9 \pm 14.81 \mathrm{c}$ & $79.0 \pm 1.58 \mathrm{~d}$ & $338.6 \pm 7.60 \mathrm{c}$ \\
\hline & & Mean & 70.8 & 2175.3 & 147.8 & 907.8 \\
\hline & \multirow{5}{*}{$\mathrm{R}_{8}$} & B1.00 & $135.0 \pm 1.34 \mathrm{~b}$ & $4012.5 \pm 36.23 c$ & $370.1 \pm 2.87 b$ & $1559.2 \pm 14.66 b$ \\
\hline & & B1.15 & $144.5 \pm 2.27 b$ & $4486.7 \pm 61.97 b$ & $409.1 \pm 4.91 \mathrm{a}$ & $1684.3 \pm 26.59 b$ \\
\hline & & B1.30 & $165.0 \pm 4.35 \mathrm{a}$ & $5006.7 \pm 180.56 a$ & $436.9 \pm 18.90 \mathrm{a}$ & $1895.7 \pm 71.88 \mathrm{a}$ \\
\hline & & B1.45 & $40.6 \pm 0.96 c$ & $1101.0 \pm 18.31 \mathrm{~d}$ & $110.3 \pm 1.56 c$ & $438.3 \pm 7.84 \mathrm{c}$ \\
\hline & & Mean & 121.3 & 3751.7 & 331.6 & 1394.4 \\
\hline
\end{tabular}

Vertical comparison, $5 \%$ significant level

\section{Effect of plow depth and soil bulk density on soybean nutrient accumulation}

Table 2 shows the changes in the dry matter and the $\mathrm{N}, \mathrm{P}$, and $\mathrm{K}$ accumulation amounts of soybean plants under the different plow depths. From Table 2, under the five plow depths, the dry matter and NPK accumulation amounts of the two test varieties increased as the growth stage progressed and increased as the plow depth increased. Specifically, in the $\mathrm{R}_{1}$ stage, the dry matter amount and the $\mathrm{N}$ accumulation amount of the two varieties showed a descending order of D40 > D30 > D20 > D10 > D0, and significant difference existed among the various treatments. The $\mathrm{P}$ accumulation amounts of the two varieties showed a descending order of D30 > D40 > D20 > D10> D0; for JY79, significant differences existed among the various treatments and for HN44; and the P accumulation amount under D30 showed no significant difference from that under D40 but was significantly higher than those under 
the other treatments. The $\mathrm{K}$ accumulation amounts of the two varieties were different because JY79 showed a descending order of D40 > D30 > D20 > D10 > D0, whereas HN44 showed a descending order of D30 $>$ D40 $>$ D20 $>$ D10 $>$ D0; for the two varieties, the $\mathrm{P}$ accumulation amount under D40 showed no significant difference from that under D30 but was significantly higher than those under the other treatments. In the $\mathrm{R}_{5}$ stage, the dry matter and the $\mathrm{N}, \mathrm{P}, \mathrm{K}$ accumulation amounts for the two test soybean varieties showed a descending order of D40 > D30 > D20>D10 > D0, and significant differences existed among the various treatments. In the $\mathrm{R}_{8}$ stage, for JY79, the dry matter and the $\mathrm{N}$ and $\mathrm{K}$ accumulation amounts showed a descending order of D40 > D30 > D20 > D10 > D0, with significant differences existing among the various treatments; the $\mathrm{P}$ accumulation amount showed a descending order of $\mathrm{D} 30>\mathrm{D} 40>\mathrm{D} 20>\mathrm{D} 10>\mathrm{D} 0$, and the P accumulation amount under D30 showed no significant difference from that accumulation under D40 but was significantly higher than those under the other treatments. For HN44, the dry matter and the N, P, and K accumulation amounts showed a descending order of D30 > D40 > D20 > D10>D0, and the dry matter and $\mathrm{K}$ accumulation amounts under D30 showed no significant difference from those under D40 but showed significant differences from those amounts under the other treatments.

\section{Effects of soil bulk density and plow depth on the root weight and root-shoot ratio in soybean}

\section{Effect of soil bulk density on the root weight and root-shoot ratio in soybean}

Table 3 shows the dynamic changes of the root weight and root-shoot ratio under the different soil bulk densities. As shown in Table 3, the root weights of the two test soybean varieties showed a single-peak curve with the increase of bulk density in the growth process, but differences existed in the changes of the root weight in the different stages among the various treatments. In the $\mathrm{R}_{1}$ and $\mathrm{R}_{5}$ stages, both varieties had the highest root weights at the bulk density of B1.15. In the $\mathrm{R}_{1}$ stage, for $\mathrm{HN} 44$, the root weight under the B1.15 treatment showed no significant difference from that under the B1.30 treatments but was significantly higher than those under the other treatments. In the $\mathrm{R}_{5}$ stage, for JY79, the root weight under the B1.15 treatment showed no significant difference from that under the B1.30 treatment but was significantly higher than those under the other treatments; however, for HN44, the root weight under the B1.15 treatment showed no significant difference from those under the B1.00 and B1.30 treatments but was significantly higher than that under the B1.45 treatment. In the $\mathrm{R}_{8}$ stage, both varieties had the highest root weights at the bulk density of B1.30. Specifically, for JY79, the root weight under the B1.30 treatment showed no significant difference from that under the B1.15 treatment but was significantly higher than those under the other treatments; for HN44, the differences in the root weight between B1.30 and the other treatments all reached the level of significance. The effect of the soil bulk density on the root-shoot ratio of the soybean plants showed that the two test varieties showed a consistent pattern. In the $\mathrm{R}_{1}$ stage, the root-shoot ratio of the soybean showed a trend in a "V"-shaped curve with the increase in the soil bulk density; the root-shoot ratio under B1.30 was the lowest and showed significant differences from those under the other treatments; and the root-shoot ratio under B1.15 showed no significant difference from that under B1.00 but was significantly lower than that under B1.45. In the $\mathrm{R}_{5}$ and $\mathrm{R}_{8}$ stages, the root-shoot ratio showed a consistent pattern: the ratio under 
B1.30 showed no significant difference from those under B1.15 and B1.00 but was significantly lower than those under the B1.45 treatment. These results showed that the soil bulk density had a great influence on the root-shoot ratio in the early growth period, but the soil bulk density had no significant effect when it was $1.00 \mathrm{~g} / \mathrm{cm}^{3}-1.30 \mathrm{~g} / \mathrm{cm}^{3}$ during the mid-to-late period; in contrast, when the soil bulk density reached $1.45 \mathrm{~g} / \mathrm{cm}^{3}$, the root-shoot ratio increased significantly.

Table 2. Effect of plow depth and soil bulk density on soybean nutrient accumulation

\begin{tabular}{|c|c|c|c|c|c|c|}
\hline Variety & Period & Dispose & $\begin{array}{l}\text { Dry matter } \\
\text { quantity } \\
\left(\mathrm{g} \cdot \text { case }^{-1}\right)\end{array}$ & $\begin{array}{c}\text { Nitrogen } \\
\text { accumulation } \\
\left(\mathrm{mg} \cdot \text { case }^{-1}\right)\end{array}$ & $\begin{array}{c}\text { Phosphorus } \\
\text { accumulation } \\
\left(\mathrm{mg} \cdot \text { case }^{-1}\right)\end{array}$ & $\begin{array}{c}\text { Potassium } \\
\text { accumulation } \\
\left(\mathrm{mg} \cdot \text { case }^{-1}\right)\end{array}$ \\
\hline \multirow{18}{*}{ JY79 } & \multirow{6}{*}{$\mathrm{R}_{1}$} & D0 & $5.8 \pm 0.15 \mathrm{~d}$ & $144.7 \pm 3.23 \mathrm{e}$ & $21.0 \pm 0.44 \mathrm{e}$ & $89.0 \pm 1.84 \mathrm{~d}$ \\
\hline & & D10 & $7.0 \pm 0.19 \mathrm{~d}$ & $204.5 \pm 5.11 \mathrm{~d}$ & $27.2 \pm 0.71 d$ & $123.0 \pm 3.42 \mathrm{c}$ \\
\hline & & D20 & $9.6 \pm 0.43 c$ & $314.7 \pm 13.98 \mathrm{c}$ & $40.8 \pm 1.78 c$ & $178.0 \pm 8.11 \mathrm{~b}$ \\
\hline & & D30 & $14.3 \pm 0.07 \mathrm{~b}$ & $484.9 \pm 3.65 b$ & $65.8 \pm 0.41 \mathrm{a}$ & $261.9 \pm 1.43 a$ \\
\hline & & D40 & $15.9 \pm 0.30 \mathrm{a}$ & $548.4 \pm 9.64 a$ & $61.5 \pm 0.80 \mathrm{~b}$ & $268.9 \pm 3.72 \mathrm{a}$ \\
\hline & & Mean & 10.5 & 339.4 & 43.3 & 184.2 \\
\hline & \multirow{6}{*}{$\mathrm{R}_{5}$} & D0 & $16.4 \pm 0.80 \mathrm{e}$ & $453.0 \pm 21.99 \mathrm{e}$ & $42.0 \pm 1.99 \mathrm{e}$ & $174.2 \pm 8.05 \mathrm{e}$ \\
\hline & & D10 & $29.9 \pm 0.10 \mathrm{~d}$ & $840.5 \pm 26.92 d$ & $83.6 \pm 2.64 d$ & $379.6 \pm 12.63 d$ \\
\hline & & D20 & $50.3 \pm 1.32 c$ & $1547.6 \pm 38.72 c$ & $143.2 \pm 3.77 \mathrm{c}$ & $671.7 \pm 17.55 c$ \\
\hline & & D30 & $58.4 \pm 1.01 \mathrm{~b}$ & $1976.6 \pm 31.90 \mathrm{~b}$ & $174.4 \pm 2.88 b$ & $793.8 \pm 13.26 b$ \\
\hline & & $\mathrm{D} 40$ & $68.9 \pm 1.57 \mathrm{a}$ & $2428.1 \pm 51.39 \mathrm{a}$ & $203.3 \pm 3.91 \mathrm{a}$ & $939.6 \pm 18.41 \mathrm{a}$ \\
\hline & & Mean & 41.8 & 1449.2 & 129.3 & 591.8 \\
\hline & \multirow{6}{*}{$\mathrm{R}_{8}$} & D0 & $42.9 \pm 1.66 \mathrm{e}$ & $1303.4 \pm 28.26 \mathrm{e}$ & $117.8 \pm 1.78 \mathrm{~d}$ & $448.8 \pm 8.07 \mathrm{e}$ \\
\hline & & D10 & $68.8 \pm 3.05 \mathrm{~d}$ & $2450.1 \pm 115.33 \mathrm{~d}$ & $248.6 \pm 13.20 \mathrm{c}$ & $832.3 \pm 39.58 \mathrm{~d}$ \\
\hline & & D20 & $106.6 \pm 1.71 \mathrm{c}$ & $3719.4 \pm 39.70 c$ & $371.7 \pm 3.67 \mathrm{~b}$ & $1186.6 \pm 13.36 c$ \\
\hline & & D30 & $144.5 \pm 1.55 b$ & $5411.6 \pm 59.57 \mathrm{~b}$ & $543.1 \pm 6.19 \mathrm{a}$ & $1726.5 \pm 20.06 b$ \\
\hline & & D40 & $168.0 \pm 2.49 \mathrm{a}$ & $6024.9 \pm 100.98 \mathrm{a}$ & $539.2 \pm 14.11 \mathrm{a}$ & $2084.9 \pm 35.35 \mathrm{a}$ \\
\hline & & Mean & 106.2 & 3781.9 & 364.1 & 1175.8 \\
\hline \multirow{18}{*}{ HN44 } & \multirow{6}{*}{$\mathrm{R}_{1}$} & D0 & $6.0 \pm 0.16 \mathrm{~d}$ & $143.8 \pm 3.86 \mathrm{e}$ & $21.4 \pm 0.57 \mathrm{~d}$ & $78.4 \pm 2.12 \mathrm{~d}$ \\
\hline & & D10 & $6.7 \pm 0.14 \mathrm{~d}$ & $176.4 \pm 4.02 \mathrm{~d}$ & $24.5 \pm 0.51 \mathrm{c}$ & $107.9 \pm 2.45 c$ \\
\hline & & D20 & $9.7 \pm 0.22 \mathrm{c}$ & $293.4 \pm 8.30 c$ & $38.3 \pm 0.99 b$ & $169.6 \pm 3.64 \mathrm{~b}$ \\
\hline & & D30 & $12.4 \pm 0.39 b$ & $384.4 \pm 11.56 b$ & $49.0 \pm 1.52 \mathrm{a}$ & $221.1 \pm 7.01 \mathrm{a}$ \\
\hline & & D40 & $14.0 \pm 0.29 \mathrm{a}$ & $453.7 \pm 5.60 \mathrm{a}$ & $47.8 \pm 0.59 a$ & $218.1 \pm 3.52 \mathrm{a}$ \\
\hline & & Mean & 9.8 & 290.3 & 36.2 & 159.0 \\
\hline & \multirow{6}{*}{$\mathrm{R}_{5}$} & D0 & $27.0 \pm 0.48 \mathrm{e}$ & $704.9 \pm 14.81 \mathrm{e}$ & $79.0 \pm 1.58 \mathrm{e}$ & $338.6 \pm 7.60 \mathrm{e}$ \\
\hline & & D10 & $33.3 \pm 0.81 \mathrm{~d}$ & $976.2 \pm 22.97 d$ & $100.1 \pm 2.54 \mathrm{~d}$ & $424.9 \pm 12.79 d$ \\
\hline & & D20 & $41.3 \pm 0.63 c$ & $1233.4 \pm 13.16 \mathrm{c}$ & $122.0 \pm 1.68 \mathrm{c}$ & $530.7 \pm 5.97 \mathrm{c}$ \\
\hline & & D30 & $69.5 \pm 0.99 b$ & $1985.1 \pm 41.53 b$ & $216.9 \pm 3.45 b$ & $905.3 \pm 15.72 b$ \\
\hline & & D40 & $86.4 \pm 1.83 a$ & $2744.0 \pm 65.22 \mathrm{a}$ & $234.5 \pm 5.11 \mathrm{a}$ & $1117.5 \pm 23.45 \mathrm{a}$ \\
\hline & & Mean & 51.5 & 1528.7 & 150.5 & 663.4 \\
\hline & \multirow{6}{*}{$\mathrm{R}_{8}$} & D0 & $40.6 \pm 0.96 \mathrm{~d}$ & $1101.0 \pm 18.31 \mathrm{e}$ & $110.3 \pm 1.56 \mathrm{e}$ & $438.3 \pm 7.84 d$ \\
\hline & & D10 & $48.6 \pm 0.90 c$ & $1441.0 \pm 31.90 \mathrm{~d}$ & $148.6 \pm 3.58 \mathrm{~d}$ & $520.6 \pm 11.58 \mathrm{c}$ \\
\hline & & D20 & $114.5 \pm 0.93 b$ & $3647.2 \pm 37.22 \mathrm{c}$ & $388.0 \pm 4.78 \mathrm{c}$ & $1310.9 \pm 15.42 b$ \\
\hline & & D30 & $147.3 \pm 1.07 \mathrm{a}$ & $4815.2 \pm 29.54 \mathrm{a}$ & $501.9 \pm 3.46 \mathrm{a}$ & $1723.4 \pm 14.78 \mathrm{a}$ \\
\hline & & D40 & $144.5 \pm 2.27 \mathrm{a}$ & $4486.7 \pm 61.97 b$ & $409.1 \pm 4.91 \mathrm{~b}$ & $1684.3 \pm 26.59 \mathrm{a}$ \\
\hline & & Mean & 99.1 & 3098.2 & 291.6 & 1135.5 \\
\hline
\end{tabular}

Vertical comparison, $5 \%$ significant level 
Table 3. Changes in the root weight and root-shoot ratio under the various soil bulk densities

\begin{tabular}{c|c|c|c|c|c}
\hline \multirow{3}{*}{ Period } & \multirow{2}{*}{ Dispose } & \multicolumn{2}{|c|}{ JY79 } & \multicolumn{2}{|c}{ HN44 } \\
\cline { 3 - 6 } & & $\begin{array}{c}\text { Root weight } \\
\left(\mathbf{g} \cdot \mathbf{c a s s}^{-1} \mathbf{)}\right.\end{array}$ & Root-shoot ratio & $\begin{array}{c}\text { Root weight } \\
\left(\mathbf{g} \cdot \mathbf{c a s e}^{-1} \mathbf{)}\right.\end{array}$ & Root-shoot ratio \\
\hline \multirow{4}{*}{$\mathrm{R}_{1}$} & B1.00 & $2.9 \pm 0.06 \mathrm{~b}$ & $0.30 \pm 0.003 \mathrm{~b}$ & $2.6 \pm 0.11 \mathrm{~b}$ & $0.26 \pm 0.010 \mathrm{~b}$ \\
& B1.15 & $3.5 \pm 0.06 \mathrm{a}$ & $0.28 \pm 0.004 \mathrm{~b}$ & $3.0 \pm 0.03 \mathrm{a}$ & $0.27 \pm 0.006 \mathrm{~b}$ \\
& B1.30 & $2.9 \pm 0.06 \mathrm{~b}$ & $0.22 \pm 0.003 \mathrm{c}$ & $2.8 \pm 0.06 \mathrm{ab}$ & $0.24 \pm 0.003 \mathrm{c}$ \\
& B1.45 & $1.5 \pm 0.06 \mathrm{c}$ & $0.35 \pm 0.010 \mathrm{a}$ & $1.6 \pm 0.04 \mathrm{c}$ & $0.36 \pm 0.001 \mathrm{a}$ \\
& Mean & 2.5 & 0.29 & 2.2 & 0.28 \\
\hline \multirow{3}{*}{$\mathrm{R}_{5}$} & B1.00 & $7.5 \pm 0.15 \mathrm{~b}$ & $0.13 \pm 0.003 \mathrm{~b}$ & $11.2 \pm 0.34 \mathrm{a}$ & $0.16 \pm 0.006 \mathrm{~b}$ \\
& B1.15 & $8.4 \pm 0.16 \mathrm{a}$ & $0.14 \pm 0.001 \mathrm{~b}$ & $11.4 \pm 0.18 \mathrm{a}$ & $0.15 \pm 0.003 \mathrm{~b}$ \\
& B1.30 & $8.2 \pm 0.05 \mathrm{a}$ & $0.12 \pm 0.003 \mathrm{~b}$ & $10.8 \pm 0.18 \mathrm{a}$ & $0.14 \pm 0.001 \mathrm{~b}$ \\
& B1.45 & $3.5 \pm 0.14 \mathrm{c}$ & $0.28 \pm 0.015 \mathrm{a}$ & $5.3 \pm 0.19 \mathrm{~b}$ & $0.25 \pm 0.017 \mathrm{a}$ \\
& Mean & 5.9 & 0.17 & 7.2 & 0.18 \\
\hline \multirow{3}{*}{$\mathrm{R}_{8}$} & B1.00 & $7.8 \pm 0.19 \mathrm{~b}$ & $0.06 \pm 0.003 \mathrm{~b}$ & $8.7 \pm 0.26 \mathrm{~b}$ & $0.07 \pm 0.001 \mathrm{~b}$ \\
& B1.15 & $8.6 \pm 0.14 \mathrm{a}$ & $0.05 \pm 0.003 \mathrm{~b}$ & $9.3 \pm 0.33 \mathrm{~b}$ & $0.07 \pm 0.003 \mathrm{~b}$ \\
& B1.30 & $8.8 \pm 0.25 \mathrm{a}$ & $0.05 \pm 0.001 \mathrm{~b}$ & $10.5 \pm 0.42 \mathrm{a}$ & $0.07 \pm 0.003 \mathrm{~b}$ \\
& B1.45 & $2.8 \pm 0.14 \mathrm{c}$ & $0.07 \pm 0.001 \mathrm{a}$ & $3.3 \pm 0.13 \mathrm{c}$ & $0.09 \pm 0.003 \mathrm{a}$ \\
& Mean & 4.9 & 0.06 & 6.6 & 0.08 \\
\hline
\end{tabular}

Vertical comparison, $5 \%$ significant level

\section{Effect of plow depth on the root weight and root-shoot ratio in the soybean}

Table 4 shows the changes in the root weight and root-shoot ratio under the different plow depths. As shown in Table 4, the root weights of the two soybean varieties during the growth process also increased as the plow depth increased. In the $\mathrm{R}_{1}$ stage, for JY79, no significant difference existed in the root weight between D40 and D30, but the root weights under these two treatments were significantly higher than those under the other treatments; for HN44, the root weight under D40 was significantly higher than those under the other treatments. In the $\mathrm{R}_{5}$ stage, the root weights for the two soybean varieties under D40 were significantly higher than those under the other treatments. In the $\mathrm{R}_{8}$ stage, for JY79, the root weight under D40 was significantly higher than those under the other treatments; for HN44, the maximum root weight was observed under D30, with the D30 root weight showing no significant difference from the weight under D40 but showing a significantly higher root weight than those under the other treatments. In addition, in terms of the effect of the plow depth on the root-shoot ratio of soybean plants, the two test varieties showed a consistent pattern because both showed a decreasing trend with the increase in plow depth. In the $\mathrm{R}_{1}$ stage, for JY79, no significant difference existed in the root-shoot ratio under D0, D20, and D30, but these ratios were significantly higher than those under D30 and D40; no significant difference existed between those ratios under D30 and D40. For HN44, no significant difference existed between D0 and D10, but their root-shoot ratios were significantly higher than those under D20, D30, and D40, with no significant difference existing among D20, $\mathrm{D} 30$, and $\mathrm{D} 40$. In the $\mathrm{R}_{5}$ stage, the two varieties showed a consistent pattern in the root-shoot ratio under D0 was significantly higher than those under D10, D20, D30, and D40, with no significant difference existing between the latter four treatments. In the $\mathrm{R}_{8}$ 
stage, for JY79, the root-shoot ratio under D0 was significantly different from those under the other treatments, with no significant difference observed among those under the D10, D20, D30, and D40 treatments; for HN44, the root-shoot ratio under D0 showed no significant difference from that under D10 but was significantly higher than those ratios under the other treatments, with no significant difference existing among those ratios under the D20, D30, and D40 treatments.

Table 4. Changes in root weight and root-shoot ratio under the various plow layers

\begin{tabular}{|c|c|c|c|c|c|}
\hline \multirow[b]{2}{*}{ Period } & \multirow[b]{2}{*}{ Dispose } & \multicolumn{2}{|c|}{ JY79 } & \multicolumn{2}{|c|}{ HN44 } \\
\hline & & $\begin{array}{l}\text { Root weight } \\
\left(\mathrm{g} \cdot \text { case }^{-1}\right)\end{array}$ & Root-shoot ratio & $\begin{array}{l}\text { Root weight } \\
\left(\mathrm{g} \cdot \operatorname{case}^{-1}\right)\end{array}$ & Root-shoot ratio \\
\hline \multirow{6}{*}{$\mathrm{R}_{1}$} & D0 & $1.55 \pm 0.05 \mathrm{~d}$ & $0.35 \pm 0.009 a$ & $1.58 \pm 0.04 \mathrm{e}$ & $0.36 \pm 0.001 \mathrm{a}$ \\
\hline & D10 & $1.82 \pm 0.04 c$ & $0.34 \pm 0.006 \mathrm{a}$ & $1.83 \pm 0.06 \mathrm{~d}$ & $0.38 \pm 0.020 \mathrm{a}$ \\
\hline & D20 & $2.56 \pm 0.13 b$ & $0.34 \pm 0.019 \mathrm{a}$ & $2.17 \pm 0.02 \mathrm{c}$ & $0.29 \pm 0.012 b$ \\
\hline & D30 & $3.32 \pm 0.05 a$ & $0.30 \pm 0.008 b$ & $2.53 \pm 0.1 b$ & $0.26 \pm 0.003 b$ \\
\hline & $\mathrm{D} 40$ & $3.47 \pm 0.06 \mathrm{a}$ & $0.28 \pm 0.004 b$ & $2.97 \pm 0.03 \mathrm{a}$ & $0.27 \pm 0.006 b$ \\
\hline & Mean & 2.69 & 0.32 & 2.51 & 0.31 \\
\hline \multirow{6}{*}{$\mathrm{R}_{5}$} & D0 & $3.54 \pm 0.14 \mathrm{~d}$ & $0.28 \pm 0.015 a$ & $5.3 \pm 0.19 c$ & $0.25 \pm 0.017 a$ \\
\hline & D10 & $3.85 \pm 0.09 \mathrm{~d}$ & $0.15 \pm 0.003 b$ & $4.97 \pm 0.11 c$ & $0.18 \pm 0.009 b$ \\
\hline & D20 & $6.24 \pm 0.18 c$ & $0.14 \pm 0.001 b$ & $5.45 \pm 0.2 c$ & $0.15 \pm 0.006 b$ \\
\hline & D30 & $7.59 \pm 0.21 b$ & $0.15 \pm 0.006 b$ & $9.05 \pm 0.24 b$ & $0.15 \pm 0.006 b$ \\
\hline & $\mathrm{D} 40$ & $8.36 \pm 0.16 a$ & $0.14 \pm 0.001 b$ & $11.43 \pm 0.18 \mathrm{a}$ & $0.15 \pm 0.003 b$ \\
\hline & Mean & 6.90 & 0.17 & 9.67 & 0.18 \\
\hline \multirow{6}{*}{$\mathrm{R}_{8}$} & D0 & $2.77 \pm 0.14 d$ & $0.07 \pm 0.001 \mathrm{a}$ & $3.28 \pm 0.13 c$ & $0.09 \pm 0.003 a$ \\
\hline & D10 & $2.78 \pm 0.03 \mathrm{~d}$ & $0.04 \pm 0.001 b$ & $3.68 \pm 0.24 \mathrm{c}$ & $0.08 \pm 0.007 \mathrm{a}$ \\
\hline & D20 & $4.71 \pm 0.38 c$ & $0.05 \pm 0.003 b$ & $7.37 \pm 0.27 b$ & $0.07 \pm 0.001 b$ \\
\hline & D30 & $5.86 \pm 0.13 b$ & $0.04 \pm 0.001 b$ & $9.49 \pm 0.51 \mathrm{a}$ & $0.07 \pm 0.003 b$ \\
\hline & $\mathrm{D} 40$ & $8.55 \pm 0.14 a$ & $0.05 \pm 0.003 b$ & $9.25 \pm 0.33 a$ & $0.07 \pm 0.003 b$ \\
\hline & Mean & 6.97 & 0.05 & 7.92 & 0.08 \\
\hline
\end{tabular}

Vertical comparison, $5 \%$ significant level

\section{Effects of the soil bulk density and plow depth on soybean yield}

Effect of the soil bulk density on the soybean yield

As shown in Table 5, the plant height, node number, grain number, 100-seed weight, and yield in the soybeans all showed a single-peak curve with the increase in the soil bulk density, with maximum values observed under the B1.30 treatment and minimum values observed under the B1.45 treatment. The plant heights of the two varieties both showed a descending order of B1.30 > B1.15 > B1.00 > B1.45. Specifically, the plant heights of JY79 under the B1.30 and B1.15 treatments showed no significant difference and were significantly higher than that under other treatments; the plant height of HN44 under B1.30 was significantly different from that under the other bulk density treatments. The node number of JY79 showed a descending order of $\mathrm{B} 1.30>\mathrm{B} 1.15>\mathrm{B} 1.00>\mathrm{B} 1.45$, with no significant difference existing between B1.30 and $\mathrm{B} 1.15$; the node number of HN44 showed a descending order of $\mathrm{B} 1.30>\mathrm{B} 1.00>\mathrm{B} 1.15>\mathrm{B} 1.45$, with B1.30 being significantly different from the other 
bulk density treatments. The grain numbers of the two varieties both showed a descending order of B1.30>B1.15>B1.00>B1.45. Specifically, the grain numbers of JY79 under B1.30 and B1.15 showed no significant difference and were significantly higher than those under the other treatments, and the grain number of HN44 under B1.30 was significantly different from the grain numbers under the other bulk density treatments. The 100-seed weights of the two varieties showed a descending order of $\mathrm{B} 1.30>\mathrm{B} 1.15>\mathrm{B} 1.00>\mathrm{B} 1.45$; the 100-seed weight under $\mathrm{B} 1.30$ showed no significant difference from those under B1.15 and B1.00 but was significantly higher than that under the B1.45 treatment. The yields of the two varieties showed a descending order of B1.30>B1.15>B1.00 > B1.45, and except for the yields of HN44 under B1.00 and B1.15 showing no significant difference, the yields under the other treatments were significantly different. The results from the SPSS regression analysis show that for the two soybean varieties, the best-fitting equation between the yield and soil bulk density is cubic: for JY79, the equation is $y=-448.923 x^{3}+799.66 x^{2}-292.617$ $\left(\mathrm{R}^{2}=0.946\right)$, and the highest yield was achieved at the bulk density of $1.19 \mathrm{~g} / \mathrm{cm}^{3}$ out of the $1.00 \mathrm{~g} / \mathrm{cm}^{3}-1.45 \mathrm{~g} / \mathrm{cm}^{3}$ range; for HN44, the equation is $\mathrm{y}=-315.164 \mathrm{x}^{3}+554.203 \mathrm{x}^{2}$ $-184.55\left(\mathrm{R}^{2}=0.899\right)$, with the yield being the greatest at $1.17 \mathrm{~g} / \mathrm{cm}^{3}$. No significant difference existed in the optimal soil bulk density between the two varieties.

Table 5. Yield components and morphology indexes under the different soil bulk densities

\begin{tabular}{|c|c|c|c|c|c|c|}
\hline Variety & Dispose & $\begin{array}{c}\text { Height } \\
(\mathbf{c m})\end{array}$ & $\begin{array}{c}\text { Node number } \\
\left(\text { nodes }^{\prime} \text { plant }^{-1}\right)\end{array}$ & 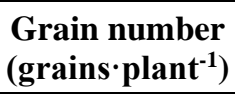 & $\begin{array}{c}100 \text {-seed } \\
\text { weight }(\mathrm{g})\end{array}$ & $\begin{array}{c}\text { Yield } \\
\left(\mathrm{g} \cdot \text { case }^{-1}\right)\end{array}$ \\
\hline \multirow{4}{*}{ JY79 } & B1.00 & $70.6 \pm 0.70 b$ & $14.2 \pm 0.44 b$ & $189.2 \pm 0.93 b$ & $18.3 \pm 0.06 \mathrm{ab}$ & $69.2 \pm 0.56 c$ \\
\hline & B1.15 & $81.8 \pm 1.27 \mathrm{a}$ & $15.3 \pm 0.33 \mathrm{ab}$ & $214.7 \pm 4.91 \mathrm{ab}$ & $19.7 \pm 0.52 \mathrm{a}$ & $84.7 \pm 0.28 b$ \\
\hline & B1.30 & $84.2 \pm 2.23 \mathrm{a}$ & $16.3 \pm 0.44 \mathrm{a}$ & $228.0 \pm 12.50 \mathrm{a}$ & $19.8 \pm 0.86 \mathrm{a}$ & $90.0 \pm 1.52 \mathrm{a}$ \\
\hline & B1.45 & $46.6 \pm 0.73 c$ & $12.3 \pm 0.33 c$ & $62.2 \pm 0.60 \mathrm{c}$ & $16.4 \pm 0.29 b$ & $20.4 \pm 0.16 d$ \\
\hline \multirow{4}{*}{ HN44 } & B1.00 & $76.6 \pm 1.67 b$ & $15.2 \pm 0.17 \mathrm{~b}$ & $160.0 \pm 4.78 \mathrm{~b}$ & $20.7 \pm 0.35 \mathrm{a}$ & $66.3 \pm 0.92 b$ \\
\hline & B1.15 & $78.0 \pm 1.67 b$ & $14.8 \pm 0.16 b$ & $169.3 \pm 3.38 b$ & $20.7 \pm 0.23 a$ & $70.2 \pm 0.88 b$ \\
\hline & B1.30 & $89.1 \pm 0.46 a$ & $16.2 \pm 0.20 \mathrm{a}$ & $188.0 \pm 4.19 \mathrm{a}$ & $20.9 \pm 0.18 \mathrm{a}$ & $78.5 \pm 1.30 \mathrm{a}$ \\
\hline & B1.45 & $43.6 \pm 1.93 c$ & $12.3 \pm 0.33 c$ & $52.5 \pm 1.76 c$ & $19.2 \pm 0.40 \mathrm{~b}$ & $20.2 \pm 1.02 \mathrm{c}$ \\
\hline
\end{tabular}

Vertical comparison, $5 \%$ significant level

\section{Effect of plow depth on soybean yield}

Table 6 shows that with the increase in plow depth, the plant height, grain number, 100 -seed weight, and yield showed increasing trends. The plant height of JY79 showed a descending order of D40 $>$ D30 $>$ D20 $>$ D10 $>$ D0; D40 showed no significant difference from D30 but showed significant differences from other various treatments. The plant height of HN44 showed a descending order of D30 > D40 > D20 > D10 > D0; D30 was significantly higher than other treatments, and D20 was not significantly different from D40 but was significantly higher than D10 and D0 treatments. The node number of JY79 showed a descending order of D40 > D20 > D30> D10 > D0; no significant differences existed among D40, D20, and D30, among D30, D20, and D10, and between D10 and D0. The node number of HN44 showed a descending order of D30 $>$ D40 $>$ D20 $>$ D0 $>$ D10, and no significant difference existed among these treatments. The grain number of JY79 showed a descending order of D40 > D30 > D20 > D10 > D0, with no significant difference existing between D40 and 
D30; the grain number of HN44 showed a descending order of D30 > D40 > D20 > D10 > D0, with no significant difference existing between D30 and D40. The 100-seed weight of JY79 showed a descending order of D40 > D30 > D20 > D10 > D0; D40 showed no significant difference between D30 and D20 but was significantly higher than D0 and D10; the 100-seed weight of HN44 showed a descending order of D30 $>$ D20 $>$ D10 $>$ D40 $>$ D0, with D30 showing no significant difference from D20 but being significantly higher than the other treatments. The yield of JY79 showed a descending order of D40 > D30 > D20>D10 > D0; D40 showed no significant difference from D30, and D40 and the yield for D30 was significantly higher than with the other treatments. The yield of HN44 showed a descending order of D30 > D40 > D20 > D10 > D0, and D30 was significantly different from the other plow depth treatments. SPSS regression analysis showed that, for the two soybean varieties, the best-fitting equation between yield and plow depth is cubic: for JY79, the equation is $y=-0.001 x^{3}+0.078 x^{2}+0.677 x+18.438\left(R^{2}=0.985\right)$, and 30$40 \mathrm{~cm}$ is the optimal plow depth range within the 0 to $40 \mathrm{~cm}$ plow range; for HN44, the equation is $\mathrm{y}=-0.005 \mathrm{x}^{3}+0.244 \mathrm{x}^{2}-1.376 \mathrm{x}+16.95\left(\mathrm{R}^{2}=0.987\right)$, with the yield being the highest at $29.4 \mathrm{~cm}$, and $27.9-30.9 \mathrm{~cm}$ is the optimal plow depth range in the 0 to $40 \mathrm{~cm}$ plow range.

Table 6. Soybean yield components and morphology indexes under the different plow depth treatments

\begin{tabular}{|c|c|c|c|c|c|c|}
\hline Variety & Dispose & $\begin{array}{l}\text { Height } \\
(\mathrm{cm})\end{array}$ & $\begin{array}{l}\text { Node number } \\
\text { (nodes'plant }{ }^{-1)}\end{array}$ & $\begin{array}{l}\text { Grain number } \\
\left(\text { grains }^{\prime} \text { plant }^{-1}\right)\end{array}$ & $\begin{array}{c}\text { 100-seed weight } \\
\text { (g) }\end{array}$ & $\begin{array}{c}\text { Yield } \\
\left(\mathrm{g} \cdot \text { case }^{-1}\right)\end{array}$ \\
\hline \multirow{5}{*}{ JY79 } & D0 & $46.6 \pm 0.73 d$ & $12.3 \pm 0.33 c$ & $62.2 \pm 3.60 \mathrm{~d}$ & $16.4 \pm 0.28 c$ & $20.4 \pm 0.36 \mathrm{~d}$ \\
\hline & D10 & $61.5 \pm 0.62 c$ & $12.7 \pm 0.44 \mathrm{bc}$ & $102.0 \pm 5.48 \mathrm{c}$ & $18.6 \pm 0.07 b c$ & $37.7 \pm 1.78 \mathrm{c}$ \\
\hline & D20 & $73.1 \pm 2.73 b$ & $14.5 \pm 0.57 \mathrm{ab}$ & $141.7 \pm 2.94 \mathrm{~b}$ & $19.3 \pm 0.43 \mathrm{ab}$ & $54.7 \pm 0.34 b$ \\
\hline & D30 & $78.1 \pm 1.99 \mathrm{ab}$ & $14.3 \pm 0.33 \mathrm{ab}$ & $189.5 \pm 4.73 \mathrm{a}$ & $21.0 \pm 0.74 \mathrm{a}$ & $79.5 \pm 2.08 \mathrm{a}$ \\
\hline & D40 & $81.8 \pm 1.27 \mathrm{a}$ & $15.3 \pm 0.33 \mathrm{a}$ & $201.3 \pm 8.41 \mathrm{a}$ & $21.3 \pm 0.69 \mathrm{a}$ & $84.7 \pm 0.28 \mathrm{a}$ \\
\hline \multirow{5}{*}{ HN44 } & D0 & $43.6 \pm 1.93 c$ & $12.3 \pm 0.33 a$ & $52.5 \pm 2.75 c$ & $19.2 \pm 0.40 \mathrm{c}$ & $20.2 \pm 1.02 \mathrm{~d}$ \\
\hline & D10 & $50.8 \pm 1.52 c$ & $12.2 \pm 0.33 \mathrm{a}$ & $55.5 \pm 2.60 \mathrm{c}$ & $21.4 \pm 0.06 b$ & $23.8 \pm 0.76 d$ \\
\hline & $\mathrm{D} 20$ & $76.2 \pm 2.39 b$ & $13.0 \pm 0.76 \mathrm{a}$ & $138.8 \pm 1.72 b$ & $22.9 \pm 0.20 \mathrm{a}$ & $63.5 \pm 2.28 c$ \\
\hline & D30 & $89.0 \pm 1.51 \mathrm{a}$ & $14.8 \pm 0.83 a$ & $172.0 \pm 1.44 \mathrm{a}$ & $23.4 \pm 0.21 \mathrm{a}$ & $80.4 \pm 1.20 \mathrm{a}$ \\
\hline & $\mathrm{D} 40$ & $78.0 \pm 1.67 b$ & $14.2 \pm 0.85 \mathrm{a}$ & $169.3 \pm 3.38 \mathrm{a}$ & $20.7 \pm 0.41 b$ & $70.2 \pm 0.88 \mathrm{~b}$ \\
\hline
\end{tabular}

Vertical comparison, $5 \%$ significant level

\section{Discussion}

\section{Appropriate soil bulk density for soybean field}

Soil bulk density is an important factor affecting soil porosity (Kaiser et al., 1991), and changes in soil bulk density cause changes in soil moisture characteristics. The changes in soil bulk density do not affect soil composition, but rather multiple soil physical indicators. The increase of soil bulk density causes significantly decreased saturated hydraulic conductivity, infiltration rate, and water diffusivity, thereby affecting crop growth and yield. A soil compaction test by Assaeed et al. (1990) found that when the bulk density was increased from $1.03 \mathrm{~g} / \mathrm{cm}^{3}$ to $1.51 \mathrm{~g} / \mathrm{cm}^{3}$, the barley yield was reduced by $29 \%$; when the bulk density was increased from $1.49 \mathrm{~g} / \mathrm{cm}^{3}$ to $1.75 \mathrm{~g} / \mathrm{cm}^{3}$, the yields of barley, corn, and peas decreased by $29 \%, 33 \%$, and $14 \%$, 
respectively; when the bulk density was increased from $1.35 \mathrm{~g} / \mathrm{cm}^{3}$ to $1.58 \mathrm{~g} / \mathrm{cm}^{3}$, the yield of peas decreased by $25 \%$. Zhang et al. (2017) studied the relation between the $\mathrm{N}$ uptake and accumulation in soybean and the soil bulk density, and found that the impact of soil bulk density on soybean yield exhibited a single-peak curve, with the optimal bulk density being $1.23 \mathrm{~g} / \mathrm{cm}^{3}-1.31 \mathrm{~g} / \mathrm{cm}^{3}$. In this experiment, the dry matter; $\mathrm{N}, \mathrm{P}$, and $\mathrm{K}$ accumulation; and the yield of soybeans showed a single-peak curve change when soil bulk density had the range of $1.00 \mathrm{~g} / \mathrm{cm}^{3}-1.45 \mathrm{~g} / \mathrm{cm}^{3}$, with the optimal bulk density being $1.30 \mathrm{~g} / \mathrm{cm}^{3}$. The experiment shows that the yields of the two test soybean varieties at the soil bulk density of $1.30 \mathrm{~g} / \mathrm{cm}^{3}$ increased, respectively, by $6.3 \%, 30.2 \%$, and $341.4 \%$ and by $11.8 \%, 18.4 \%$, and $289.3 \%$, respectively, compared to their yields at bulk densities of $1.15 \mathrm{~g} / \mathrm{cm}^{3}, 1.00 \mathrm{~g} / \mathrm{cm}^{3}$, and $1.45 \mathrm{~g} / \mathrm{cm}^{3}$. The difference in yield was small between the bulk densities of $1.30 \mathrm{~g} / \mathrm{cm}^{3}$ and $1.15 \mathrm{~g} / \mathrm{cm}^{3}$, and $1.15 \mathrm{~g} / \mathrm{cm}^{3}-1.30 \mathrm{~g} / \mathrm{cm}^{3}$ could be considered the appropriate range of bulk density for soybean growth. Therefore, when the bulk density is lower than $1.15 \mathrm{~g} / \mathrm{cm}^{3}$, the soil needs to be compacted properly, and when the bulk density is higher than $1.30 \mathrm{~g} / \mathrm{cm}^{3}$, the soil needs to be cultivated and loosened.

Significant differences exist in the soil bulk density under the different tillage measures, and as the soil bulk density increases, the number of pea root nodules and the dry weight of the root nodule, as well as the $\mathrm{N}$-fixation enzyme activities and the total N content, would increase accordingly (Siczek and Lipiec, 2011; Siczek et al., 2013). Buttery et al. (1998) also found that in the clay loam, when the soil bulk density was increased from $1.2 \mathrm{~g} / \mathrm{cm}^{3}$ to $1.5 \mathrm{~g} / \mathrm{cm}^{3}$, the dry matter amount and the root weight of the soybean declined by $76.7 \%$ and $68.2 \%$, respectively; in sandy loam, when the soil bulk density was increased from $1.2 \mathrm{~g} / \mathrm{cm}^{3}$ to $1.6 \mathrm{~g} / \mathrm{cm}^{3}$, the dry matter amount and the root weight of the soybean were reduced by $70.5 \%$ and $48.1 \%$, respectively. In this study, the soybean root weight also showed a single-peak curve trend with the increase in the soil bulk density. Specifically, the maximum values for the two test varieties in the $R_{1}$ and $R_{5}$ stages occurred under the treatment with the bulk density of $1.15 \mathrm{~g} / \mathrm{cm}^{3}$, and the maximum value in the $\mathrm{R}_{8}$ stage occurred under the treatment with the bulk density of $1.30 \mathrm{~g} / \mathrm{cm}^{3}$. When the bulk density was increased to $1.45 \mathrm{~g} / \mathrm{cm}^{3}$, the root weight was decreased significantly, which agreed with the findings of Buttery et al. (1998).

The increase in soil bulk density obstructs the growth of crop roots and of plants and results in thickened roots and poor nutrient uptake, leading to changes in crop root-shoot ratio. The root-shoot ratio of the soybean can indicate the distribution of the dry matter in the root and aboveground parts. Bengough et al. (1994) argued that when the soil bulk density increased from $0.85 \mathrm{~g} / \mathrm{cm}^{3}$ to $1.40 \mathrm{~g} / \mathrm{cm}^{3}$, the growth rate of the pea roots declined significantly; when the root growth resistance increased, the root elongation rate in the pea decreased by $50 \%$ within half an hour, and upon the removal of the resistance, the root growth rate increased slightly. In this experiment, the root-shoot ratios of the two test soybean varieties were high during the early growth period and decreased with the progression of the growth stages. The change of soil bulk density did not alter the pattern of gradual decrease in the root-shoot ratio during the progression of the soybean growth stages. However, a significant difference occurred in the root-shoot ratio among the different bulk density treatments. In the $\mathrm{R}_{1}$ stage, the root-shoot ratio showed a "V"-pattern change with the increase of soil bulk density and reached its minimum value at the soil bulk density of $1.30 \mathrm{~g} / \mathrm{cm}^{3}$. The root-shoot ratios in the $R_{5}$ and $R_{8}$ stages showed no significant 
difference among the treatments with the soil bulk densities of $1.00 \mathrm{~g} / \mathrm{cm}^{3}, 1.15 \mathrm{~g} / \mathrm{cm}^{3}$, and $1.30 \mathrm{~g} / \mathrm{cm}^{3}$, but the ratios were significantly lower than those observed under the treatment with the soil bulk density of $1.45 \mathrm{~g} / \mathrm{cm}^{3}$. Notably, the treatment with the soil bulk density of $1.30 \mathrm{~g} / \mathrm{cm}^{3}$ was the most conducive to the growth of soybean, with the dry matter and the N, P, and K accumulation amounts being the highest when the rootshoot ratio was the smallest and the treatment with the soil bulk density of $1.45 \mathrm{~g} / \mathrm{cm}^{3}$ being the most unfavorable to the growth of soybean when the root-shoot ratio was the highest. These results indicate that when the soil bulk density was too high, root growth was hindered, and soybean plants had to allot more dry matter to the root system, resulting in an increase in the root-shoot ratio. When the soil was too loose (i.e., the bulk density was too low), bulk density only had a significant influence on the root-shoot ratio in the early soybean growth period; in contrast, excessive bulk density had a significant impact on the entire growth period.

\section{Appropriate plow depth for the soybean field}

Increased tillage and subsoiling depth can effectively reduce the soil bulk density in the lower layer and increase the plow depth, promoting crop growth and yield increase. Wang et al. (2015) conducted a comparative study between subsoiling of 30 $\mathrm{cm}$, rotary tillage of $10 \mathrm{~cm}$, and no-till treatments, and they found that the bulk density in the 20 to $30 \mathrm{~cm}$ soil layer under the subsoiling treatment decreased by $10.3 \%$ compared with that under the rotary tillage and no-till treatments; under the subsoiling treatment, the dry matter in the corn showed an increase, and the yield was $8.9 \%$ and $10.6 \%$ higher, respectively, than that under rotary tillage and no-tillage. Johnson et al. (1989) found that with a plow depth of $0-30 \mathrm{~cm}$, the yield of crops gradually would increase with the increase of plow depth and would not increase significantly below the plow depth of $30 \mathrm{~cm}$. Gaultney et al. (1980) noted that the soil compaction of the lower soil layers can significantly affect the growth and final yield of corn. Increasing the subsoiling depth can effectively reduce the soil bulk density in the lower soil layers (Wang et al., 2015), and with the increase in plow depth, the crop yield also increases (Nunes et al., 2015b). In this experiment, the dry matter and the N, P, and K accumulation amounts of plants increased as the growth stage progressed. Among the two test soybean varieties, for JY79, the accumulation of dry matter and of N, P, and $\mathrm{K}$ and yield during the three sampling periods showed an increasing trend with the increase in plow depth, with the maximum values occurring under the $40 \mathrm{~cm}$ plow depth treatment (albeit, no significant difference in yield existed between the $30 \mathrm{~cm}$ and $40 \mathrm{~cm}$ plow depth treatments). For HN44, the dry matter, the $\mathrm{N}, \mathrm{P}$, and $\mathrm{K}$ accumulation amounts, and the yield in the $\mathrm{R}_{8}$ stage all had a single-peak curve, with the maximum value occurring under the $30 \mathrm{~cm}$ plow depth treatment.

Increased plow depth promotes soybean root growth toward the lower soil layers. In this experiment, the root weights of the two test soybean varieties showed an increasing trend with the increase of plow depth in the three sampling periods, but the root-shoot ratio decreased with the increase of growth stage and plow depth. Plow depth had a large impact on the root-shoot ratio during the early soybean growth period but had a small impact during the late growth period. In the $\mathrm{R}_{1}$ stage, no significant difference was observed in the root-shoot ratio between the 0 to $10 \mathrm{~cm}$ plow depths, but the root-shoot ratios for these two depths were significantly higher than those for the $30 \mathrm{~cm}$ and $40 \mathrm{~cm}$ plow depths, whereas no significant difference existed between the $30 \mathrm{~cm}$ and the $40 \mathrm{~cm}$ plow depths. In the $\mathrm{R}_{5}$ and $\mathrm{R}_{8}$ stages, only 
the $0 \mathrm{~cm}$ treatment had a relatively large root-shoot ratio, and no significant difference existed among the other depths. The above results showed that increasing the plow depth promotes the growth of aboveground parts of soybean and underground root systems, and it also promotes the distribution of nutrients toward the aboveground parts.

According to Qi et al. (2015), traction resistance in subsoiling increases quadratically with depth, with the subsoiling depths of $10 \mathrm{~cm}, 20 \mathrm{~cm}, 30 \mathrm{~cm}$, and 40 $\mathrm{cm}$ showing resistance values of $0.42 \mathrm{kN}, 0.85 \mathrm{kN}, 2.56 \mathrm{kN}$, and $5.49 \mathrm{kN}$, respectively. In this test, the average yield of the two test soybean varieties showed an increase of $92.2 \%$ in yield when the plow depth was increased from $10 \mathrm{~cm}$ to $20 \mathrm{~cm}$ and an increase of $35.3 \%$ in yield when the plow depth was increased from $20 \mathrm{~cm}$ to $30 \mathrm{~cm}$. When the plow depth increased from $30 \mathrm{~cm}$ to $40 \mathrm{~cm}$, JY79 showed an increase in yield of $6.5 \%$ but without a significant difference; HN44 did not show an increase in yield. When the plow depth was greater than $30 \mathrm{~cm}$, the increase in soybean yield was not significant, but the traction resistance during field preparation increased greatly, resulting in a significant increase in the operating costs. Therefore, a plow depth of $30 \mathrm{~cm}$ for soybean field setting is appropriate.

\section{Conclusions}

(1) Soybean dry matter; N, P, and K accumulation amounts; and yield exhibited a single-peak curve change when the bulk density reach a range of $1.00 \mathrm{~g} / \mathrm{cm}^{3}-1.45$ $\mathrm{g} / \mathrm{cm}^{3}$, with $1.15 \mathrm{~g} / \mathrm{cm}^{3}-1.30 \mathrm{~g} / \mathrm{cm}^{3}$ being the appropriate ranges for soybean growth and yield formation. The soybean dry matter; the N, P, and K accumulation amounts; and the yield increased with the increase in plow depth. When the plow depth increased from $30 \mathrm{~cm}$ to $40 \mathrm{~cm}$, the two test soybean varieties did not show a significant increase in yield, and the $30 \mathrm{~cm}$ plow depth could thus be determined to be the appropriate plow depth for the soybean field.

(2) The root-shoot ratio of the soybean plants was higher at the early growth period and decreased as growth progressed; the changes in bulk density and plow depth in the plow layer had a greater impact on the root-shoot ratio in the early soybean growth period, but they did not alter the pattern where the root-shoot ratio gradually decreased during the growth of the soybean. In the $\mathrm{R}_{1}$ stage, the root-shoot ratio exhibited a "V"-shaped trend for change as the bulk density in the plow layer increased, with the minimum root-shoot ratio occurring under the $1.30 \mathrm{~g} / \mathrm{cm}^{3}$ treatment; in the $\mathrm{R}_{5}$ and $\mathrm{R}_{8}$ stages, the root-shoot ratio was not significantly affected when the bulk density in the plow layer was $1.00 \mathrm{~g} / \mathrm{cm}^{3}-1.30 \mathrm{~g} / \mathrm{cm}^{3}$, but the root-shoot ratio significantly increased under the $1.45 \mathrm{~g} / \mathrm{cm}^{3}$ treatment. In the $\mathrm{R}_{1}$ stage, no significant difference was observed in the root-shoot ratio between the 0 to $20 \mathrm{~cm}$ plow depth treatments, and their root-shoot ratios were higher than those under the treatments with the $30 \mathrm{~cm}$ and $40 \mathrm{~cm}$ plow depths; in the $\mathrm{R}_{5}$ and $\mathrm{R}_{8}$ stages, the rootshoot ratio was not significantly different between the 10 to $40 \mathrm{~cm}$ plow depth treatments.

Acknowledgements. The National Key Research and Development Program of China (2016YFD0300803); the Applied Technology Research and Development Program of Heilongjiang Province (GA16B401). 


\section{REFERENCES}

[1] Assaeed, A. M., Mcgowan, M., Hebblethwaite, P. D., Brereton, J. C. (1990): Effect of soil compaction on growth, yield, and light interception of selected crops. - Annals of Applied Biology 117: 653-666.

[2] Barley, K. P. (1962): The effects of mechanical stress on the growth of roots. - Journal of Experimental Botany 2: 175-185.

[3] Bengough, A. G., Mackenzie, C. J., Elangwe, H. E. (1994): Biophysics of the growth responses of pea roots to changes in penetration resistance. - Plant and Soil 167: 135-141.

[4] Blouin, V., Schmidt, M., Bulmer, C., Krzic, M. (2004): Soil compaction and water content effects on lodgepole pine seedling growth in British Columbia. - SuperSoil 2004: 3rd Australian New Zealand Soils Conference, 5-9 December 2004, University of Sydney.

[5] Bushamuka, V. N., Zobel, R. W. (1998): Differential genotypic and root type penetration of compacted soil layers. - Crop Science 38: 776-781.

[6] Buttery, B. R., Tan, C. S., Drury, C. F., Park, S. J., Armstrong, R. J., Park, K. Y. (1998): The effects of soil compaction, soil moisture and soil type on growth and nodulation of soybean and common bean. - Revue Canadienne De Phytotechnie 78: 571-576.

[7] Chai, H., He, N. P. (2016): Evaluation of soil bulk density in Chinese terrestrial ecosystems for determination of soil carbon storage on a regional scale. - Acta Ecologica Sinica 36(13): 1-7.

[8] Colombi, T., Walter, A. (2016): Root responses of triticale and soybean to soil compaction in the field are reproducible under controlled conditions. - Functional Plant Biology 43(2): 114-128.

[9] Freitas, P. L. D., Zobel, R. W., Synder, V. A. (1999): Corn root growth in soil columns with artificially constructed aggregates. - Crop Science 39: 725-730.

[10] Fu, H., Liu, X. (2017): A study on the impact of environmental education on individuals' behaviors concerning recycled water reuse. - Eurasia Journal of Mathematics Science and Technology Education 13(10): 6715-6724.

[11] Gaultney, L., Krutz, G. W., Steinhardt, G. C., Liljedahl, J. B. (1980): Effects of subsoil compaction on corn yield in Indiana. - ASAE Paper 25.

[12] Gayosso-Moralesl, M. A., Nandini, S., Martinez-Jeronimo, F. F., Sarma, S. S. S. (2017): Effect of organic and inorganic turbidity on the zooplankton community structure of a shallow waterbody in Central Mexico (Lake Xochimilco, Mexico). - Journal of Environmental Biology. 38(6SI): 1183-1196.

[13] Gomez-Lopez, V. M., Buitrago, M. E., Tapia, M. S., Martinez-Yepez, A. (2018): Effect of ultrasonication on sensory and chemical stability of passion fruit juice during refrigerated storage. - Emirates Journal of Food and Agriculture 30(1): 85-89.

[14] Goss, M. J., Russell, R. S. (1980): Effects of mechanical impedance on root growth in barley (Hordeum vulgare L.) III. Observations on the mechanism of response. - Journal of Experimental Botany 31: 577-588.

[15] Iijima, M., Kono, Y., Yamauchi, A., Pardales Jr, J. R. (1991): Effects of soil compaction on the development of rice and maize root systems. - Environmental and Experimental Botany 31(3): 333-342.

[16] Johnson, J. F., Voorhees, W. B., Nelson, W. W., Randall, G. W. (1989): Soybean growth and yield as affected by surface and subsoil compaction. - Agronomy Journal 81: 973979.

[17] Kaiser, E. A., Heisler, C., Walenzik, G., Heinemeyer, O. (1991): Effects of soil compaction on development of microbial biomass, soil fauna (Collembola), denitrification and mineralization in an arable soil. - Mitteilungen der Deutschen Bodenkundlichen Gesellschaft 110: 385-388. 
[18] Maganti, M., Weaver, S., Downs, M. (2005): Responses of spreading orach (Atriplex patula) and common lambsquarters (Chenopodium album) to soil compaction, drought, and waterlogging. - Weed Science 53: 90-96.

[19] Nunes, M. R., Denardin, J. E., Pauletto, E. A., Faganello, A., Pinto, L. F. S. (2015a): Effect of soil chiseling on soil structure and root growth for a clayey soil under no-tillage. - Geoderma s 259-260: 149-155.

[20] Nunes, M. R., Denardin, J. E., Pauletto, E. A., Faganello, A., Pinto, L. F. S. (2015b): Mitigation of clayey soil compaction managed under no-tillage. - Soil and Tillage Research 148: 119-126.

[21] Peng, W., Ge, S., Ebadi, A. G., Hisoriev, H., Esfahani, M. J. (2017): Syngas production by catalytic co-gasification of coal-biomass blends in a circulating fluidized bed gasifier. - Journal of Cleaner Production 168: 1513-1517.

[22] Qi, G. Y., Liu, L., Zhao, Y. Z., Gong, Z. P., Yang, Y. Q., Yang, Y. (2015): Effects of subsoiler's penetrating depth and spade shape on traction resistance. - Journal of Agricultural Mechanization Research 2015(11).

[23] Rosolem, C. A., Schiochet, M. A., Souza, L. S., Whitacker, J. P. T. (1998): Root growth and cotton nutrition as affected by liming and soil compaction. - Communications in Soil Science and Plant Analysis 29: 169-177.

[24] Siczek, A., Lipiec, J. (2011): Soybean nodulation and nitrogen fixation in response to soil compaction and surface straw mulching. - Soil and Tillage Research 114: 50-56.

[25] Siczek, A., Lipiec, J., Wielbo, J., Szarlip, P., Kidaj, D. (2013): Pea growth and symbiotic activity response to Nod factors (lipo-chitooligosaccharides) and soil compaction. Applied Soil Ecology 72: 181-186.

[26] Siczek, A., Horn, R., Lipiec, J., Usowicz, B., Łukowski, M. (2015): Effects of soil deformation and surface mulching on soil physical properties and soybean response related to weather conditions. - Soil and Tillage Research 153: 175-184.

[27] Stypa, M., Nunez-Barrios, A., Barry, D. A., Miller, M. H., Mitchell, W. A., Stypa, M., Nunez-Barrios, A., Barry, D. A., Miller, M. H., Mitchell, W. A. (1987): Effects of subsoil bulk density, nutrient availability and soil moisture on corn root growth in the field. Canadian Journal of Soil Science 67: 293-308.

[28] Ufuk Kasim, M., Kasim, R. (2017): Yellowing of fresh-cut spinach (Spinacia oleracea L.) Leaves delayed by UV-B applications. - Information Processing in Agriculture 4(3): 214219.

[29] Vicente-Molina, M. A., Fernandez-Sainz, A., Izagirre-Olaizola, J. (2018): Does gender make a difference in pro-environmental behavior? The case of the Basque Country University students. - Journal of Cleaner Production 176: 89-98.

[30] Wang, X., Zhou, B., Sun, X., Yue, Y., Ma, W., Zhao, M. (2015): Soil tillage management affects maize grain yield by regulating spatial distribution coordination of roots, soil moisture and nitrogen status. - PloS One 10: e0129231.

[31] Williams, M. A., Rice, C. W. (2007): Seven years of enhanced water availability influences the physiological, structural, and functional attributes of a soil microbial community. - Applied Soil Ecology 35: 535-545.

[32] Zhang, X. T., Cao, L. W., Lv, S. C., Chen, G. X., Wang, Y. J., Yu, S. H., Gong, Z. P. (2017): Effects of bulk density on nitrogen absorption and yield of soybean on black soil. - Crops 2017: 132-137.

[33] Zhao, Z., Huang, Y., Ma, C., Gong, Z., Yang, Y., Song, Q., Dong, S., Zhang, L. (2010): Effects of tillage practices on soybean field soil moisture and soil bulk density. - Journal of Agricultural Mechanization Research 2010(7): 181-184. 